\title{
THE SPATIAL INTEGRATION OF POTATO WHOLESALE MARKETS OF UTTARAKHAND IN INDIA
}

\author{
A. Kumar* and R. Mishra \\ Department of Agricultural Economics, G. B. Pant University of Agriculture \& \\ Technology, Pantnagar-263145, U S Nagar, Uttarakhand, India
}

\begin{abstract}
This paper analyzes the spatial integration of potato markets in Uttarakhand using monthly wholesale price for ten years. The maximum likelihood method of cointegration developed by Johansen (1988) was used in the study. The dynamics of short-run price responses were examined using vector error correction model (VECM). The results indicated that five potato markets reacted on the long-run cointegrating equations while the speed of price adjustment in the short-run was almost absent. Moreover, it was found that the longer the distance between the markets, the weaker the integration was. To increase the efficiency of potato markets in Uttarakhand, there is need to focus on building an improved market information system. This system should be able to disseminate timely market information about price, demand and supply of produce to enable producers, traders and consumers to make proper production and marketing decisions.
\end{abstract}

Keywords: Potato, wholesale, spatial, integration

\section{INTRODUCTION}

The nature of markets and their role in price determination are central to economies. Spatial price behaviour in regional markets is an important indicator of overall market performance. Typically, agricultural products are bulky and/or perishable and area of production and consumption are separated; hence, transportation is costly. To measure demand and supply, price discovery, and structure of competition, geographical boundaries of a market are important. The geographical integration of markets determines the extent to which weather risk is shared over space by smoothing idiosyncratic price variations. Integrated markets have limited price differences in time, form, and space when it comes to marketing costs. Markets that are not integrated may convey inaccurate price signals that might distort producers' marketing decisions and contribute to inefficient product

\footnotetext{
*Corresponding author email: rozni.mishra13@gmail.com
} 
movements (Tomek and Robinson, 1990). If price movements of a commodity in one market are completely irrelevant to forecast price movements of the same commodity in other markets, the markets are characterized as segmented. The success of opening up of trade between the regions will depend on the strength of transmission of price signals among the markets in various regions of a country. The spread of price information is an important factor that affects market. Uttarakhand produces large varieties of cereals, fruits, vegetables and spices. The total area and production under potato was 24.7 thousand hectare and 4.09 lakh tons, respectively while the yield was 16.58 tons per hectare during 2013-14 (Uttarakhand at a Glance 2014-15). Nainital district is the leading producer of potato followed by Almora an Udham Singh Nagar. Kharif potatoes are mostly taken in hilly districts viz. Dheradun, Almora, Pithoragarh, Nainital and Uttarkashi while Rabi potato is grown in plains of Udham Singh Nagar and Haridwar but in very less area. Haldwani (HAL) and Dehradun (DDN) wholesale markets are the main market for potato in Uttarakhand. However, due to absence of sound marketing facility, the farmers have to depend on local traders and middlemen for disposal of their farm produce to these wholesale markets. Further, the distance from the market yard influences the marketing behaviour of the producer. The various costs involved in transporting the produce especially the perishable one from point of production to market yard is of grave concern for the producer. Detailed research in this part is limited and necessitates an indepth study of marketing of potato in relation to spatial integration is necessary. In this back drop, the present study was carried out to examine the spatial price relationship of potato in different wholesale markets of Uttarakhand.

\section{DATA AND METHODOLOGY}

The data set employed in the cointegration exercise consisted of monthly wholesale prices of potato from January 2005 to December 2015. There are 25 principal markets in Uttarakhand of which five are not yet functional and among 20 markets only 15 markets were selected due to constrained of unavailability of consistent data from the period under consideration. Therefore, the data related to wholesale prices of potato were collected from Mandi Samiti office of each market. On that basis, the following market centres were chosen: Bazpur (BAZ), Dehradun (DDN), Gadarpur (GAD), Haldwani (HAL), Haridwar (HAR), Jaspur (JAS), Kashipur (KAS), Khatima (KHA), Kichha (KIC), Ramnagar (RAM), Rishikesh (RIS), Rudrapur (RUD), Sitarganj (SIT), Tanakpur (TAN) and Vikasnagar (VIK).

The most common methodology used in the past for testing market integration involved the estimation of bivariate correlation coefficient between price changes in different markets, e.g., Cummings (1967) and Lele (1967, 1971). This method was strongly criticized due to methodological flaws by Blyn (1973), Harriss (1979), Heytens (1986) and Ravallion (1986, 1987). The most significant contribution to market integration methods came from Ravallion (1986), however this method involves serious problems that result in inefficient estimators. Meanwhile, Palaskas 
and Harriss-White's (1993) study involves serious methodological defects inherent in the Engle and Granger (1987) method of cointegration which does not provide any procedure of testing multiple cointegrating vectors having three or more variables. PHW identifying the central and the peripheral markets on the basis of population data, volumes, and direction of flows of commodities and nodes of transport networks. However, this is not the safest way to eliminate the possibility of an endogeneity problem because prices are often determined simultaneously. A better way to resolve the problem is to use the multivariate cointegration method developed by Johansen (1988). This method treats all the variables as explicitly endogenous and takes care of the endogeneity problem by providing an estimation procedure that does not require an arbitrary choice of a variable for normalization. It also allows tests for multiple cointegrating vectors. The present study analyzes the spatial integration of potato wholesale markets in the Uttarakhand state by using recently developed cointegration techniques.

Two markets are considered spatially integrated if the price in the importing market $\left(\mathrm{P}_{\mathrm{t}}^{\mathrm{i}}\right)$ is equal to the price in the exporting market $\left(\mathrm{P}_{\mathrm{t}}^{\mathrm{e}}\right)$ including transport and other transfer costs in moving goods between them( $\left(\mathrm{T}_{t}^{\mathrm{ie}}\right)$. This happens because of spatial arbitrage condition given by $\mathrm{P}_{\mathrm{t}}^{\mathrm{i}}=\mathrm{P}_{\mathrm{t}}^{e}+\mathrm{T}_{\mathrm{t}}^{\mathrm{ie}}$. However, market integration does not necessarily imply that markets are competitive. Generally, the approaches that are used for testing market integration may be classified into two broad categories. First, Law of One Price (LOP), tests for perfect co-movement of prices and assumes that if markets are integrated, price changes in the exporting market will be transmitted to the importing markets on a one-for-one basis. LOP requires that trade flows between two markets must occur in every period and prices in one market are determined exogenously. However, these are highly restrictive assumptions that are satisfied rarely in reality. To avoid some of these problems, a second approach, i.e., cointegration is used to test for a more general notion of spatial market integration. A cointegration test can be used even when the co-movement of prices is less than perfect, prices are determined simultaneously, and there are seasonal variations in transfer costs. LOP holds if there are $n-1$ cointegrating vectors and thus all $n$ number of prices contains a common stochastic trend. It is for these reasons, and because most prices tend to be non-stationary, cointegration in terms of a long-run linear relationship between prices. The most utilized cointegration test is EngleGranger test. However, since this test involves several problems, the present study employed the ML method of cointegration. This method allows the testing of multiple cointegrating vectors in a multivariate framework. Since this test is carried out in a reduced form vector autoregressive (VAR) model, it does not involve the endogeneity problem. As such, the test results remain invariant to the choice of the variable selected for normalization in the regression. 
A cointegration test does not require the examination of the univariate timeseries properties of the data. It confirms that all price series are non-stationary and integrated in the same order. This is performed using the Augmented Dickey-Fuller (ADF) test developed by Dickey and Fuller $(1979,1981)$. The test is based on the statistics obtained from applying the Ordinary Least Squares (OLS) method to the following regression equation:

$$
\Delta \mathrm{P}_{\mathrm{t}}=\alpha+\theta \mathrm{P}_{\mathrm{t}-1}+\sum_{\mathrm{i}=1}^{\mathrm{k}} \gamma_{\mathrm{i}} \Delta \mathrm{P}_{\mathrm{t}-\mathrm{i}}+\varepsilon_{\mathrm{t}}
$$

Where: $\mathrm{k}=$ number of lagged difference terms required so that the error term $\varepsilon_{\mathrm{t}}$ is serially independent. To determine whether $\mathrm{P}_{\mathrm{t}}$ is non-stationary, the tau-statistic $(\hat{\tau}), \hat{\tau}=\frac{\hat{\theta}-1}{\operatorname{se}(\hat{\theta})}$ is used to test the unit-root null hypothesis $H_{0}: \theta=0$. Since $\hat{\tau}$ does not have the usual properties of student-t distribution, there is need to use critical values tabulated by Fuller (1979) for testing the level of significance. The lagged first difference terms are included in the equations to take care of possible correlation in the residuals. If the unit-root null is rejected for the first-difference of the series but cannot be rejected for the level, then the series contains one unit root and is integrated of order one, I (1). The lag length, at which the prices are mostly integrated, was defined using VAR on the differenced series. In VAR analysis, Akaike Information Criterion (AIC) and Schwartz Criterion (SC) were used to select a suitable lag length. This is important because the inclusion of excessive lagged terms will introduce the problem of multicollinearity. Meanwhile, very few lags will lead to specification error. The lower the values of AIC and SC statistic, the better the model is.

\section{Cointegration test}

If $\mathrm{P}_{\mathrm{t}}$ denotes an $(\mathrm{n} \times 1)$ vector of I (1) prices, then the k-th order VAR representation of $\mathrm{P}_{\mathrm{t}}$ may be written as:

$$
P_{t}=\sum_{i=1}^{k} \Pi_{i} P_{t-1}+\varepsilon_{t} \quad(t=1,2, \ldots \ldots, T)
$$

The procedure for testing cointegration is based on the error correction (ECM) representation of $\mathrm{P}_{\mathrm{t}}$ given by:

$$
\Delta \mathrm{P}_{\mathrm{t}}=\sum_{\mathrm{i}=1}^{\mathrm{k}-1} \Gamma_{\mathrm{i}} \Delta \mathrm{P}_{\mathrm{t}-\mathrm{i}}+\Pi \mathrm{P}_{\mathrm{t}-\mathrm{k}}+\varepsilon_{\mathrm{t}}
$$

Where: $\Gamma_{i}=-\left(I-\Pi_{1}-\ldots .,-\Pi_{t}\right) ; i=1,2, \ldots . ., k-1 ; \Pi=-\left(I-\Pi_{1}-\ldots .,-\Pi_{k}\right)$;

Each of $\Pi_{I}$ is $n \times n$ matrix of parameters; $\varepsilon_{\mathrm{t}}$ is an independently distributed $\mathrm{n}$ dimensional vector of residuals with zero mean and variance matrix. Since $\mathrm{P}_{\mathrm{t}-\mathrm{k}}$ is $\mathrm{I}$ (1), but $\Delta \mathrm{P}_{\mathrm{t}}$ and $\Delta \mathrm{P}_{\mathrm{t}-\mathrm{i}}$ variables are I (0), equation (2) will be balanced if $\Pi \mathrm{P}_{\mathrm{t}-\mathrm{k}}$ is I (0). So, it is the $\Pi$ matrix that conveys information about long-run relationship among the variables in $\mathrm{P}_{\mathrm{t}}$. The rank of $\Pi$, $r$, determines the number of cointegrating 
vectors, as it determines how many linear combinations of $P_{t}$ is stationary. If $r=n$, the prices are stationary in levels. If $r=0$, no linear combination of $P_{t}$ is stationary. If $0<\operatorname{rank}(\Pi)=\mathrm{r}<\mathrm{n}$ (Walter Enders, 1995), and there are $\mathrm{n} \times \mathrm{r}$ matrices $\alpha$ and $\beta$ such that $\Pi=\alpha \beta$, then it can be said that there are $r$ cointegrating relations among the elements of $\mathrm{P}_{\mathrm{t}}$. The cointegrating vector $\beta$ has the property that $\beta{ }^{\prime} \mathrm{P}_{\mathrm{t}}$ is stationary even though $\mathrm{P}_{\mathrm{t}}$ itself is non-stationary. The matrix $\alpha$ measures the strength of the cointegrating vectors in the ECM, as it represents the speed of adjustment parameters. Two likelihood ratio test statistics are proposed. The null hypothesis of $r$ cointegrating vector against a general alternative hypothesis of more than $r$ cointegrating vectors is tested by the

Trace Statistic $(\lambda$-trace $)=-\mathrm{T} \sum_{\mathrm{i}=\mathrm{r}+1}^{\mathrm{n}} \operatorname{In}\left(1-\widehat{\lambda_{1}}\right)$.

The null of exactly $r$ cointegrating vectors against the alternative of $r+1$ is tested by the Maximum Eigen value statistic $(\lambda-\max )=-\operatorname{TIn}\left(1-\widehat{\lambda}_{\mathrm{r}+1}\right)$.

$\hat{\lambda}_{\bar{i}} \mathrm{~s}$ are the estimated values of the characteristic roots, which are also called Eigen values, obtained from the estimated $\Pi$ matrix; $T$ is the number of usable observations. The number of cointegrating vectors indicated by the tests is an important indicator of the extent of co-movement of the prices. An increase in the number of cointegrating vectors implies an increase in the strength and stability of price linkages.

\section{RESULTS AND DISCUSSION}

The estimated test statistics from ADF tests for wholesale prices of potato in levels and first differences are reported in table 1.

Table 1. Results of the ADF test for the order of Integration

\begin{tabular}{l|c|c|c|c|c|c}
\hline \multirow{2}{*}{ Markets } & \multicolumn{3}{|c|}{ Unit Root on Price Level } & \multicolumn{3}{c}{ Unit Root on First Difference } \\
\cline { 2 - 7 } & Coefficient & t-value & p-value & Coefficient & t-value & p-value \\
\hline BAZ & -0.881 & -9.610 & 0.000 & - & - & - \\
DEH & -0.424 & -3.180 & 0.001 & -1.362 & -15.55 & 0.000 \\
GAD & -0.203 & -3.860 & 0.004 & -1.159 & -12.65 & 0.000 \\
HAL & -0.104 & -2.416 & 0.139 & -0.910 & -9.539 & 0.000 \\
HAR & -1.104 & -3.711 & 1.000 & -2.096 & -4.395 & 0.000 \\
JAS & -0.003 & -0.284 & 0.922 & -1.148 & -12.51 & 0.000 \\
KAS & -0.013 & -0.488 & 0.883 & -2.553 & -9.069 & 0.000 \\
KHA & -0.080 & -1.535 & 0.512 & -3.804 & -8.065 & 0.000 \\
KIC & -0.100 & -2.563 & 0.103 & -2.747 & -8.107 & 0.000 \\
RAM & -0.152 & -2.680 & 0.080 & -1.329 & -14.24 & 0.000 \\
\hline
\end{tabular}




\begin{tabular}{l|ccc|c|c|c}
\hline \multirow{2}{*}{ Markets } & \multicolumn{3}{|c|}{ Unit Root on Price Level } & \multicolumn{3}{c}{ Unit Root on First Difference } \\
\cline { 2 - 7 } & Coefficient & $\mathrm{t}$-value & $\mathrm{p}$-value & Coefficient & $\mathrm{t}$-value & $\mathrm{p}$-value \\
\hline RIS & -0.233 & -3.195 & 0.022 & -1.356 & -15.28 & 0.000 \\
RUD & -0.037 & -1.117 & 0.266 & -2.061 & -8.614 & 0.000 \\
SIT & -0.067 & -1.749 & 0.403 & -1.752 & -7.580 & 0.000 \\
TAN & -0.162 & -3.070 & 0.031 & -0.967 & -10.31 & 0.000 \\
VIK & -0.178 & -4.058 & 0.001 & -2.165 & -3.293 & 0.000 \\
\hline
\end{tabular}

Notes: Critical value of $\mathrm{t}$ statistics is -2.88 at 5 per cent level of significance. ADF analysis was carried out in EVIEWS.

It can be seen that the null hypothesis of non-stationarity cannot be rejected for wholesale prices in levels, but can be rejected in first differences. Therefore, wholesale prices are non-stationary in their levels but stationary in first differences. This implies that all wholesale price series contained a single unit root and were integrated of order one. As such, taking first differences as variables in the model eliminates the stochastic trend in the nominal series.

The cointegration tests were then conducted since the entire wholesale price series were integrated of the same order. The integration of potato markets of Uttarakhand was evaluated by investigating the long-run relationship between the wholesale price series of potato in spatially separated locations of Uttarakhand.

The results of the multivariate cointegration tests for wholesale price series of potato crop in Uttarakhand are reported in table 2. The main task was to examine the rank $\Pi$ or the number of cointegrating vectors for wholesale price series of potato. Using the cointegration test available in EVIEWS, the rank of $\Pi$ was determined. The $\lambda$-max test, also known as ML ratio test, was more powerful than the trace test. The $\lambda$-max test indicated the presence of 5 cointegrating vector for wholesale markets of potato at 5 percent level of significance and the test defined the rank of $\Pi=5$. The above empirical evidence suggests that the wholesale price series of all the markets of potato in Uttarakhand were cointegrated to a long-run equilibrium. The farmers transfer their produce from one market to the other according to the price changes. Meanwhile, arbitrage through trade ties their prices together. 
Table 2. Cointegration results for spatial integration of wholesale markets of potato in Uttarakhand

\begin{tabular}{cccccc}
\hline & Trace test & \multicolumn{3}{c}{ Maximum Eigen Value test } \\
\hline $\begin{array}{c}\text { Null } \\
\text { Hypothesis }\end{array}$ & $\lambda$-trace & $\begin{array}{c}5 \% \text { critical } \\
\text { Value }\end{array}$ & $\begin{array}{c}\text { Null } \\
\text { Hypothesis }\end{array}$ & $\lambda$-max & $\begin{array}{c}5 \% \text { critical } \\
\text { Value }\end{array}$ \\
\hline $\mathrm{r}=0$ & 932.44 & $\mathrm{NA}$ & $\mathrm{r}=0$ & 158.19 & $\mathrm{NA}$ \\
$\mathrm{r} \leq 1$ & 774.25 & $\mathrm{NA}$ & $\mathrm{r}=1$ & 151.09 & $\mathrm{NA}$ \\
$\mathrm{r} \leq 2$ & 623.15 & $\mathrm{NA}$ & $\mathrm{r}=2$ & 134.10 & $\mathrm{NA}$ \\
$\mathrm{r} \leq 3^{*}$ & 489.04 & 334.98 & $\mathrm{r}=3^{*}$ & 111.93 & 76.57 \\
$\mathrm{r} \leq 4^{*}$ & 377.11 & 285.14 & $\mathrm{r}=4^{*}$ & 91.77 & 70.53 \\
$\mathrm{r} \leq 5^{*}$ & 285.33 & 239.23 & $\mathrm{r}=5^{*}$ & 75.25 & 64.50 \\
$\mathrm{r} \leq 6$ & 210.08 & 197.37 & $\mathrm{r}=6$ & 58.40 & 58.43 \\
\hline
\end{tabular}

Note: *denotes rejection of the hypothesis at 5 percent significance level.

For the long-run price cointegration in wholesale markets of potato in Uttarakhand, the cointegrating equations that were normalized according to the rank are shown in table 3 . Five cointegrating equations were obtained for potato by normalizing with respect to BAZ, DEH, GAD, HAL and HAR wholesale prices. The results of long-run wholesale price integration using Johansen's ML test could explain why BAZ was integrated with most of the wholesale markets to which it distributed the potato crop as the transit market. Further, BAZ was highly integrated with JAS, KIC, RUD, and SIT markets. Similarly, DEH market was highly integrated with JAS, KIC, KHA, RAM, RIS and VIK markets, which showed that the shorter distance made the integration stronger. However, HAL market was integrated with KIC, RAM, RUD, SIT and KHA markets and has weaker integration with other markets which shows the longer distance lead the integration weaker. This fact was also explained in the case of HAR markets which is not integrated with TAN and SIT markets.

Table 3. Estimation of long-run wholesale price integration of potato markets

\begin{tabular}{|c|c|c|c|c|c|c|}
\hline \multirow[t]{2}{*}{$\begin{array}{l}\text { BAZ } \\
=\end{array}$} & $\begin{array}{c}-16.67 \text { JAS } \\
(-3.255)^{*}\end{array}$ & $\begin{array}{c}+5.123 \\
\text { KAS } \\
(1.196)\end{array}$ & $\begin{array}{c}-5.060 \mathrm{KHA} \\
(-1.330)\end{array}$ & $\begin{array}{c}+46.431 \\
\mathrm{KIC} \\
(7.088)^{*}\end{array}$ & $\begin{array}{c}+4.036 \\
\text { RAM } \\
(1.096)\end{array}$ & \multirow{2}{*}{ CointEq (1) } \\
\hline & $\begin{array}{c}+13.66 \text { RIS } \\
(2.228)\end{array}$ & $\begin{array}{c}-14.165 \\
\text { RUD } \\
(-3.383)^{*}\end{array}$ & $\begin{array}{c}-18.641 \text { SIT } \\
(-4.486)^{*}\end{array}$ & $\begin{array}{c}-1.482 \text { TAN } \\
(-0.502)\end{array}$ & $\begin{array}{c}-1.921 \mathrm{VIK} \\
(-0.431)\end{array}$ & \\
\hline \multirow[t]{2}{*}{$\begin{array}{l}\text { DEH } \\
=\end{array}$} & $\begin{array}{c}-3.402 \text { JAS } \\
(-3.611)^{*}\end{array}$ & $\begin{array}{c}-1.668 \mathrm{KAS} \\
(-2.119)\end{array}$ & $\begin{array}{c}-2.457 \\
\text { KHA } \\
(-3.515)^{*}\end{array}$ & $\begin{array}{c}+4.764 \mathrm{KIC} \\
(3.953)^{*}\end{array}$ & $\begin{array}{c}+2.385 \\
\text { RAM } \\
(3.522)^{*}\end{array}$ & \multirow{2}{*}{ CointEq (2) } \\
\hline & $\begin{array}{c}+1.018 \text { RIS } \\
(2.348)^{*}\end{array}$ & $\begin{array}{c}-0.322 \\
\text { RUD } \\
(0.418)\end{array}$ & $\begin{array}{c}+1.772 \text { SIT } \\
(2.310)\end{array}$ & $\begin{array}{c}+2.568 \\
\text { TAN } \\
(1.738)\end{array}$ & $\begin{array}{c}-2.713 \text { VIK } \\
(-3.316)^{*}\end{array}$ & \\
\hline
\end{tabular}




\begin{tabular}{|c|c|c|c|c|c|c|}
\hline \multirow[t]{2}{*}{$\begin{array}{l}\text { GAD } \\
=\end{array}$} & $\begin{array}{c}-2.719 \text { JAS } \\
(-2.785)^{*}\end{array}$ & $\begin{array}{c}+1.328 \\
\text { KAS } \\
(1.586)\end{array}$ & $\begin{array}{c}+2.300 \\
\text { KHA } \\
(3.091)^{*}\end{array}$ & $\begin{array}{c}+7.011 \mathrm{KIC} \\
\quad(5.468)^{*}\end{array}$ & $\begin{array}{c}-0.730 \text { RAM } \\
(-1.013)\end{array}$ & \multirow{2}{*}{ CointEq (3) } \\
\hline & $\begin{array}{c}+1.029 \text { RIS } \\
(1.281)\end{array}$ & $\begin{array}{c}-2.624 \\
\text { RUD } \\
(-3.204)^{*}\end{array}$ & $\begin{array}{c}-4.955 \text { SIT } \\
(-6.095)^{*}\end{array}$ & $\begin{array}{c}-2.327 \text { TAN } \\
(-4.039)^{*}\end{array}$ & $\begin{array}{c}+5.534 \mathrm{VIK} \\
(2.867)^{*}\end{array}$ & \\
\hline \multirow[t]{2}{*}{$\begin{array}{l}\text { HAL } \\
=\end{array}$} & $\begin{array}{c}+1.081 \mathrm{JAS} \\
(0.487)\end{array}$ & $\begin{array}{c}+1.292 \\
\text { KAS } \\
(0.696)\end{array}$ & $\begin{array}{c}+7.010 \\
\text { KHA } \\
(4.248)^{*}\end{array}$ & $\begin{array}{c}+6.170 \mathrm{KIC} \\
(2.842)^{*}\end{array}$ & $\begin{array}{c}-5.379 \text { RAM } \\
(-3.368)^{*}\end{array}$ & \multirow{2}{*}{ CointEq (4) } \\
\hline & $\begin{array}{c}+1.769 \text { RIS } \\
(0.993)\end{array}$ & $\begin{array}{c}-6.680 \\
\text { RUD } \\
(-3.678) *\end{array}$ & $\begin{array}{l}-7.818 \text { SIT } \\
(-4.338)^{*}\end{array}$ & $\begin{array}{c}-2.166 \text { TAN } \\
(-1.694)\end{array}$ & $\begin{array}{c}+5.504 \mathrm{VIK} \\
(2.051)\end{array}$ & \\
\hline \multirow[t]{2}{*}{$\begin{array}{l}\text { HAR } \\
=\end{array}$} & $\begin{array}{c}+1.752 \mathrm{JAS} \\
(3.319)^{*}\end{array}$ & $\begin{array}{c}-3.114 \mathrm{KAS} \\
(-7.452)^{*}\end{array}$ & $\begin{array}{c}+0.133 \\
\text { KHA } \\
(0.338)\end{array}$ & $\begin{array}{c}-0.134 \mathrm{KIC} \\
(-0.197)\end{array}$ & $\begin{array}{c}+0.692 \\
\text { RAM } \\
(1.821)\end{array}$ & \multirow{2}{*}{ CointEq (5) } \\
\hline & $\begin{array}{c}-1.485 \text { RIS } \\
(-3.502)^{*}\end{array}$ & $\begin{array}{c}+0.968 \\
\text { RUD } \\
(2.241)\end{array}$ & $\begin{array}{c}+0.535 \mathrm{SIT} \\
(1.247)\end{array}$ & $\begin{array}{c}+0.890 \text { TAN } \\
(2.027)\end{array}$ & $\begin{array}{c}-1.389 \text { VIK } \\
(-3.019)^{*}\end{array}$ & \\
\hline
\end{tabular}

Note: All the values in parentheses are t-values

*Significant at 1 percent level of significance and critical $t$-value $=2.32$

Testing for short-run integration can be incorporated in the Vector Error Correction Model (VECM) using the same price series, only when the long-run integration is observed. The short-run dynamics of wholesale prices of potato is presented in table 4. A principal feature of cointegrated variables is that their time paths are influenced by the extent of any deviation from long-run equilibrium (Walter Enders, 1995). After all, if the system is to return to the long-run equilibrium, the movement of at least some of the variables must respond to the magnitude of the disequilibrium. The larger the coefficient of the cointegrating relation in the regression, the stronger the reaction of the markets in the short-run. It is seen from the table that BAZ was the strongest follower of the cointegrating equation one with a speed of adjustment of about 15 percent while DEH was the strongest follower of cointegrating equation 2 with a speed of adjustment of 70 percent. KHA and HAL markets were the strongest follower of cointegrating equation 3 and 4, respectively and further HAR market was the follower of cointegrating equation 4 with speed of adjustment of 45 per cent. In general, it can be said that BAZ, DEH, HAL and HAR markets are special markets as they reacted to all the cointegrating equations. The cointegration results observed a strong long-run relationship of wholesale prices between all the markets for potato in Uttarakhand. However, the results of errorcorrection reveal a very weak association between these vegetable markets in the short-run. The significant short-run association was missing in most of the cases. Thus, it may be concluded from the above analysis that while prices are tied together in the long-run, they drift apart in the short-run because of paucity of availability of information and lack of quicker dissemination of available information. 


\section{A. Kumar and R. Mishra}

Table 4. Estimation of short-run dynamics of wholesale prices of potato in Uttarakhand

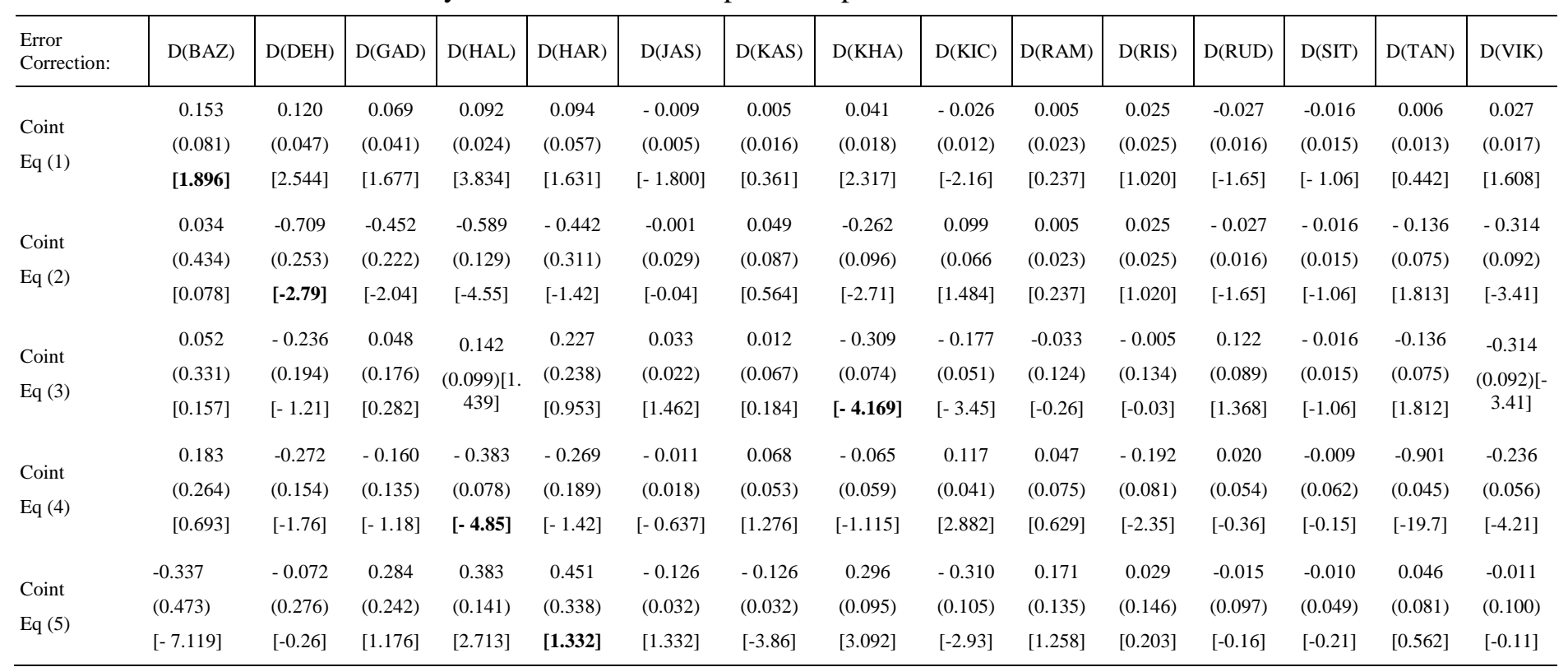

Note: All the figures in parentheses (....) are standard error and figures in [....] are t-values 
A. Kumar and R. Mishra

\section{CONCLUSION AND POLICY IMPLICATIONS}

Market integration reflects price linkages when there is trade between two markets to test and measure its extent. Using monthly wholesale price data for ten years, this paper analyzed the spatial integration of potato markets in Uttarakhand. From the results, it was observed that the wholesale markets of perishable crop potato had integration in the long-run. This may be due to the fact that the production of potato is more concentrated in hills compared to other vegetables. The concentrated production urges traders and consumers to focus on production and marketing, and this makes the prices in other markets move with the prices of production areas to a greater degree. These were found to be segmented with the markets of plain area and signifies that the longer the distance, the lesser the integration. The results show that due to lack of available, timely information on price, lack of transportation facilities, product characteristics, and large distance between the markets made the markets segmented. In general, Bazpur, Dehradun, Haldwani and Haridwar markets are special markets as they reacted to all the cointegrating equations. It was observed that there is a strong long-run relationship of wholesale prices between all the markets for potato in Uttarakhand. However, the results further reveal a very weak association between these vegetable markets in the short-run. The reason might be the paucity of availability of information, lack of dissemination of available information, and transportation conditions. In Uttarakhand, it will usually take a long time to transport commodities from one province to another because of limited transportation facilities. These prevent the traders from responding immediately to price changes in other markets.

The results of this study show that potato markets in Uttarakhand are integrated in the long-run. However, the degree of short-run market integration is rather low. Therefore, in potato markets, the transmission of price information is slow and price changes across areas are not responsive to each other. To make the potato markets in Uttarakhand more efficient, there is a need to focus on building an improved market information system-one that is able to disseminate timely market information about price, demand, and supply of products to enable producers, traders, and consumers to make proper production and marketing decisions. The monitoring results of the Information Centre of Ministry of Agriculture of Uttarakhand and relative units like the Marketing Development Board on agricultural products supply, demand, and price should be shared timely and accurately to producers, traders, and consumers through various communication media. This can help farmers and traders understand well the trends of production and marketing. In turn, they will be able to make better decisions as well as realize higher returns in the process and thus help consumers to get the product at a reliable price. The government is also required to create market infrastructure facilities like transportation, warehousing, and processing, among others. 


\section{ACKNOWLEDGEMENT}

The financial assistant from National Institute of Agricultural Economics and Policy Research (NIAP) and ICAR for its project "Network Project on Market Intelligence" on which paper is based is duly acknowledged. The authors are grateful to Dr. Ramesh Chand, Director, NIAP, Dr. P. S. Brithal, Principal Scientist and Dr. Raka Saxena, Senior Scientist \& PI, for their valuable suggestions.

\section{REFERENCES}

Blyn, G. 1973. Price Series Correlation as a measure of Market Integration. Indian Journal of Agricultural Economics, 28: 56-59

Cummings, R. W. 1967. Pricing Efficiency in the Indian Wheat Market. New Delhi: Impex, India

Dickey, D. A. and Fuller, W. A. 1979. Distribution of Estimators for Autoregressive Time Series with Unit Roots. Journal of the American Statistical Association, 74: 112-143

Dickey, D. A. and Fuller, W. A. 1981. Likelihood Ratio Statistics for Autoregressive Time Series with a Unit Root. Econometrica, 49: 1057-1072

Engle, R. F. and Granger, C. W. J. 1987. Cointegration and Error Correction: Representation, Estimation and Testing. Econometrica, 55: 251- 276

Harriss, B.1979. This is Method in My Madness: Or Is It Vice Versa? Measuring Agricultural Market Performance. Food Research Institute Studies, 17: 197-218

Heytens, P. J. 1986. Testing Market Integration. Food Research Institute Studies, 20: 25-41

Johansen, S. 1988. Statistical Analysis of Cointegration Vectors. Journal of Economic Dynamics and Control, 12: 231-254

Johansen, S. and Juselius, K.1990. Maximum Likelihood Estimation and Inference on Cointegration with Application to the Demand for Money. Oxford Bulletin of Economics and Statistics, 52:169-210

Lele, U. J. 1967. Market Integration: A Study of Sorghum Prices in Western India. Journal of Farm Economics, 49:147-159

Lele, U. J. 1971. Foodgrain Marketing in India: Private Performance and Public Policy. New York: Cornell University Press, Ithaca

Palaskas, T. B. and Harriss-White, B. 1993. Testing Market Integration: New Approach with Case Material from the West Bengal Food Economy. Journal of Development Studies, 30:1-57

Ravallion, M.1986. Testing Market Integration. American Journal of Agricultural Economics, 68:102-109

Ravallion, M. 1987. Markets and Famines, Oxford: Clarendon Press, UK

Tomek, W. G. and Robinson, K. L. 1990. Agricultural Product Prices. USA: Cornell University Press, Ithaca

Walter Enders. 1995. Applied Econometric Time Series. USA: John Wiley and Sons Inc 